American and Colonial, which are again sub-divided into alphabetical and classified sections; in the case of the British, a Geographical Section has been added, making in all nine sub-divisions.

Photography as a Hobby. "The Popular Photographic

Series." By Matthew Surface. Pp. 60. (London: Percy

Lund, Humphries, and Co., L.td., 1897.)

THIs little book is intended for those who amuse themselies with photography. The author shows how many a pleasant hour may be spent with the camera, and describes rambles he himself has made. These are very well illustrated, and the reader will gather from them that it is not necessary to go very far afield for subjects, as these are always close at hand if one only has the capacity for picking them out. The author describes also how, during unfavourable weather, the "hobby" may be carried on in the house. The book is very neatly got up, and will afford those who indulge in photography as a hobby with a pleasant hour's reading.

First Records of British Flowering Plants. Compiled

by William A. Clarke, F.L.S. Pp. Io3. (London

West, Newman, and Co., I 897.)

To satisfy commendable curiosity, it is often required to know who first observed a particular plant, when and where it was first found, and how long it has been known as a British plant. The answers to these questions will be found in Mr. Clarke's handy little volume. The earliest notice of each distinct species of British flowering plants has been found by searching through printed botanical works published in Great Britain, and the extracts thus obtained have been brought together in this work. The list contains altogether I 440 species, the nomenclature of which is based upon the eighth edition of the "London Catalogue." The earliest records referred to are from William Turner's works, ranging from 1538 to 1568 .

On Human Noture. By Arthur Schopenhauer. Translated by T. Bailey Saunders, M.A. Pp. I32. (London: Swan Sonnenschein and Co., Ltd., I897.)

HUMAN nature as understood by that most pessimistic of philosophers, Schopenhauer, is here presented in English dress by Mr. Saunders. The essays which make up the book have been selected and translated from Schopenhauer's Parergi. They deal with human nature in various aspects, and their tendency is to make a man suspicious of all people, distrustful of all motives, and doubtful whether civilised life is real or only a big masquerade.

Tabellen für Gasanalysen, gasvolumetrische Analysen, Stickstofbestimmungen,

(Braunschweig: Friedrich Vieweg und Sohn, I897.)

THESE tables will be found of service in chemical laboratories in which gas analyses, and volumetric determination of gases, are made. One of the tables is for the reduction of the observed volume of a gas to the temperature of $0^{\circ}$, and the other enables the observed volume to be reduced to a pressure of $760 \mathrm{~mm}$. Together the tables thus furnish the means for reducing volumes of gases to standard temperature and pressure.

The Larice of the British Butterfies and Moths. By the late William Buckler. Vol. vii. Edited by Geo.

T. Porritt, F.L.S. Pp. I76. 22 plates. (London: Ray Society, 1897.)

THE first volume on the larve of the British butterflies and moths appeared in 1885 ; the present volume contains the first portion of the Geometra, and this group will be completed in vol. viii. The twenty plates illustrating the larva described are extremely fine, and the whole volume is a worthy addition to an invaluable series.

No. I 429, VOL. 55]
LETTERS TO THE EDITOR.

[The Editor does not hold himself responsible for opinions expressed by his correspondents. Neither can he undertake to return, or to correspond with the writers of, rejected manuscripts intended for this or any other part of NATURE. No notice is taken of anonymous communications.]

The Measurement of Pressures in the Bore of Guns.

I' has been stated that many gunpowders which have given fairly satisfactory results in a small bore, have developed dangerous pressure when tried in cannon; and also that similar experiments with cordite showed no signs of any approach to such a "critical point.". Further, cordite is said to burn quietly when thrown in boxes of $100 \mathrm{lbs}$. upon a bonfire, and yet to be as suitable for ordnance as for small arms. But cordite did not prove so tractable on its late trial in Plumstead Marshes. It is plain, therefore, that explosive forces of all powders depend very much upon the conditions under which they are ignited.

Hence arises a pressing necessity for some satisfactory method of determining the maximum explosive force which every adopted powder is capable of exerting when fired in rifled guns of small and large calibre. The chronoscopic method of solving the problem was brought forward thirty years ago, under the then Ordnance Select Committee, but I have never met with a single example fairly worked out for a rifled gun, so as to show precisely what could be found by that method. My difficulty was stated in NATURE (March 14, 1895), but hitherto without result, except that the President of the British Association, in his address at Ipswich (September I895), stated that-

"In the gun, by means of electrical contacts arranged in the bore, a time-curve of the passage of the shot can be determined. From this the mathematician constructs the velocity-curve, and from this, again, the pressures producing the velocity are estimated (?) and used to check the same indications obtained by other means (p. 29)."

Now, beside the "pressures producing the velocity" of the shot in rifled guns, there is an additional force arising from friction, \&c., which greatly adds to the pressure of the powder gas tending to burst the gun. Hence, if we denote by $\mathrm{P}$ this pressure of the powder gas on the base of the shot, and by $F$ the retarding pressure of friction, \&c., at the same instant, then the resultant driving pressure acting on the shot will be denoted by $(\mathrm{P}-\mathrm{F})$ at that instant. If now the projectile be made to trace an accurate time-curve, it will be possible to deduce from this time-curve the value of the driving pressure $(\mathrm{P}-\mathrm{F})$ acting on the shot at every point. But the grand object is to find $P$, the pressure of the powder gas tending to burst the gun, and not $(\mathrm{P}-\mathrm{F})$ the pressure driving the shot, which is given by the chronoscope. Therefore the chronoscopic method of experimenting fails to give the whole pressure of the powder gas, which tends to burst the rifled gun; and this method gives nothing which can be "used to check the same indications obtained by other means," simply because $(\mathrm{P}-\mathrm{F})$ is not given by other means. The chronoscopic method of experimenting fails when any part of the pressure $(F)$ of the powder gas is not instrumental in producing motion. From what has been said, the chronoscopic method must fail, even under the most favourable circumstances, when rifled guns are used.

But the perfect accuracy in experiment we have assumed can. not be secured practically. The most critical point is at the instant the shot begins to move. But no chronoscope which registers by points can make the smallest pretence to give the initial time-curve accurately.

The only way to find the pressure of the powder gas at any point in the bore of a rifled gun is to use a modification of Rumford's or Rodman's method, which measures directly the pressure in the bore at any point.

The vast importance of this subject to the nation at this time must be my excuse for troubling you a second time.

Minting Vicarage, March 4.

F. BASHFORTH.

\section{A Powerful and Efficient Means of Driving X-Ray Tubes.}

DURING the last few months the limitations of the present induction coil, especially as a means of driving X-ray tubes and vacuum tubes in general, have been so clearly brought before us that we have given the subject considerable attention. It is 